\title{
Oxidative Stress and Genetic Polymorphism of Superoxide Dismutase in Sickle Cell Disease Patients in South-Eastern Nigeria
}

\author{
Okonkwo Cyril Onyedikachi ${ }^{*}$, Eze Emmanuel A², Onyia Felix Chukwuemeka ${ }^{3}$, Ejiagha Maria- \\ Regina Chekwube ${ }^{4}$ and Ocheni Sunday ${ }^{5}$ \\ ${ }^{1}$ Biotech Lab, Department of Biological Sciences, Godfrey Okoye University, Emene, Enugu, Nigeria \\ ${ }^{2}$ Department of Microbiology, University of Nigeria, Nsukka, Nigeria \\ ${ }^{3}$ Department of Biological Sciences, Godfrey Okoye University, Emene, Enugu, Nigeria \\ ${ }^{4}$ Department of Science Laboratory Technology, Akanu Ibiam Federal Polytechnic, Unwana, Afikpo, Ebonyi State, Nigeria \\ ${ }^{5}$ Department of Haematology \& Immunology, College of Medicine, University of Nigeria, Ituku-Ozalla Campus, Enugu State, Nigeria \\ *Corresponding author: Okonkwo Cyril Onyedikachi, Graduate Student, Medical Biotechnology Programme, Department of \\ Biological Sciences, Godfrey Okoye University, Ugwuomu-Nike, Enugu State, P.M.B. 01014 Thinker's Corner, Enugu, Nigeria
}

\section{ARTICLE INFO}

Received: 幽 October 20, 2021

Published: 慧 November 09, 2021

Citation: Okonkwo Cyril Onyedikachi, Eze Emmanuel A, Onyia Felix Chukwuemeka, Ejiagha Maria-Regina Chekwube, Ocheni Sunday. Oxidative Stress and Genetic Polymorphism of Superoxide Dismutase in Sickle Cell Disease Patients in South-Eastern Nigeria. Biomed J Sci \& Tech Res 39(5)-2021. BJSTR. MS.ID.006366.

Keywords: Mn-SOD; Genotype; Polymorphism; Sickle Cell Disease; SNP; Oxidative Stress

Abbreviations: Mn-SOD: ManganeseSuperoxide Dismutase; SNP: Single Nucleotide Polymorphism; SCD: Sickle Cell Disease; ROS: Reactive Oxygen Species; GPx: Gluthathione Peroxidase; Prx: Peroxiredoxin; GSH: Reduced Glutathione; PCR: Polymerase Chain Reaction

\section{ABSTRACT}

Background: Sickle cell disease (SCD) is a form of haemoglobinopathy which affects the structure of the haemoglobin by genetically substituting Valine for Glutamate at position 6 of the amino acid linear sequence of the protein. In SCD, oxidative stress is increased and believed to play a significant role in the pathophysiology of SCDrelated crisis. It has been found that a structural mutation of thymine (T) to cytosine (C) substitution in the coding sequence of manganese-superoxide dismutase (Mn-SOD) gene, which changes the amino acid codon at 9th position in the signal peptide from valine (GTT) to alanine (GCT), is implicated in various disease states.

Aim: This work was aimed at investigating the relationship between oxidative stress and genetic polymorphism of manganese-superoxide dismutase in patients with SCD visiting the University of Nigeria Teaching Hospital (UNTH) Ituku-Ozalla, Enugu state, south-Eastern Nigeria.

Materials and Methods: The study recruited a total of 50 subjects which include 20 Sickle cell anaemia patients (SS), 15 sickle cell carriers (AS) and 15 healthy non-carriers (AA). DNA was extracted from venous blood samples; PCR amplification was done using specified primers to the region of polymorphism and finally followed by restriction enzyme digestion.

Results and Discussion: The results in the test group showed val/val genotype frequency to be 0.67 , ala/ala 0.27 and val/ala 0.06 . In the control groups, the results seem to show an opposite trend, in which there is val/val frequency of 0.15 , ala/ala 0.5 and val/ala of 0.35 . There is, therefore, a predominance of val/val genotype in the test group whereas there is more ala/ala in the control group, which could be said to be an association of the polymorphism with the SCD, contrary to some previous works.

Conclusion: The findings of this research suggest that Ala-9-Val polymorphism in Mn-SOD gene is associated with SCD, and therefore could act as genetic modifier of phenotypic outcome of these patients in the region under study. 


\section{Introduction}

Sickle cell disease (SCD) is a group of disorders that affect haemoglobin, the protein in red blood cells that delivers oxygen to cells throughout the body. This is diseases was discovered in 1910 according to reported literature [1]. Historically, SCD is said to have its birthplace in Africa, where in many tribes, those who are sicklers are tattooed to identify them as "Ogbanje" (Children who come and go) due to the high infant mortality seen among them within Africa, as illustrated in African medical literature which reported sickle cell disease condition in the 1870s [2,3]. It is an inherited blood disorder resulting from a point mutation involving a thymine (T) for adenine (A) (from a GAG to GTG) substitution at codon 6 of the beta-globin chain leading to the substitution of Valine for Glutamate at position 6, hence, shifting the isoelectric point of the protein [4]. It is an autosomal recessive disease identified by their sickle-shaped red blood cells and accelerated haemolysis resulting to anaemia. Those who have this trait in homozygous state present severe anaemia, while those who have it in heterozygous (sickle cell carriers) usually do not show symptoms [5]. The sickled red blood cells $(\mathrm{HbS})$ are more rigid than normal ones ( $\mathrm{HbA})$, which results to micro-vascular occlusion leading to "crisis" that is characterized by episodes of severe pain, increased susceptibility to secondary infections, leg ulcers, bone infarcts, and other infarctions with tissue death possibibly occurring in almost all organs (skin, liver, spleen, bone, kidneys, retina, CNS) [5-8]. The anaemia part of this disease is caused by the destruction of the red blood cells, because of their shape. Much as bone marrow try to compensate this shortfall in the number of red blood cells by creating new ones, the production rate does not match the rate of destruction. Healthy red blood cells typically function for 90-120 days, but sickled red blood cells only last for 10-20 days [9]. Signs of sickle cell anaemia usually begin in early childhood. The severity of symptoms of sickle cell anaemia varies from person to person [10]. HbS is the most dangerous and most common of all haemoglobinopathies. There are other forms of haemoglobinopathies such as $\alpha$-thalassaemia and $\beta$-thalassaemia [11], $\mathrm{HbC}, \mathrm{HbE}, \mathrm{Hb}$ Johnstown and other less common variants of haemoglobin [7,12-14].

According to reports, approximately $5 \%$ of the world population has some types of haemoglobinopathy, and more than 300,000 babies are born each year with one form of haemoglobin disorder or the other, with sickle cell anaemia being the dorminant type $[15,16]$. The prevalence of live births with the disease is estimated at $4.4 \%$ in the world, with the rates remaining high on the continents of Africa, Southeast Asia and the Americas. The frequency of sickle cell trait ranges from 10 to $45 \%$ in various parts of Sub-Saharan Africa [17-19]. In Nigeria, the prevalence of those presenting the disease in heterozygous form is about 20 to $30 \%$ [20]. Sickle cell anaemia affects about 2 to $3 \%$ of the Nigerian population of more than
160 million people. Oxidative stress is described as an imbalance between oxidants or free radicals or reactive oxygen species (ROS) and antioxidants in favor of the former [21,22]. ROS are produced as a result of normal intracellular catabolism that requires oxygen as a terminal electron acceptor (oxidant). During this process, ROS such as superoxide $\left(\mathrm{O}_{2}{ }^{\circ}\right)$, hydrogen peroxide $\left(\mathrm{H}_{2} \mathrm{O}_{2}\right)$ and hydroxyl radicals $\left(\mathrm{OH}_{2}\right)$ are produced as intermediates, even in healthy individuals [23,24]. In SCD, oxidative stress is increased and believed to play a significant role in the pathophysiology of SCDrelated microvascular dysfunction, vasoocclusion, and development of organ damage $[25,26]$.

A high production rate of reactive oxygen species (ROS) in SCD is caused by factors such as increased intravascular haemolysis, ischemia-reperfusion injury, and chronic inflammation $[27,28]$. Several mechanisms contribute to the high oxidative burden in sickle cell patients, including: the excessive levels of cell-free hemoglobin with its catalytic action on oxidative reactions, the characteristic recurrent ischemia-reperfusion injury, a chronic proinflammatory state, higher autoxidation of sickle hemoglobin (HbS), increased xanthine oxidase activity in sickle cell disease aortic endothelium, and higher number of leucocytes, which produce twice the number of fluxes of superoxide in sickle cell disease [29-31]. Oxidative stress can damage specific molecular targets (lipids, proteins, nucleotides etc.), resulting in cell dysfunction and/or death [32]. Major defense mechanisms against ROS include enzymatic (superoxide dismustase (SOD), catalase, gluthathione peroxidase (GPx), peroxiredoxin (Prx) as well as non-enzymatic antioxidant system (reduced glutathione (GSH)), ubiquinols, uric acid, vitamins $\mathrm{C}$ and E, flavonoids, carotenoids) [33]. Enzymatic antioxidants work by breaking down and removing free radicals. The antioxidant enzymes convert dangerous oxidative products to hydrogen peroxide $\left(\mathrm{H}_{2} \mathrm{O}_{2}\right)$ and then to water, in a multi-step process in the presence of cofactors such as copper, zinc, manganese, and iron. Non enzymatic antioxidants work by interrupting free radical chain reactions. However, supplementation of sickle cell patients with many of these antioxidant minerals and nutrients such as zinc, vitamins $\mathrm{C}$ and $\mathrm{E}$, flavonoids and carotenoids do not accomplish clinically measurable ameliorating effect, such as reducing the degree of hemolysis, as reported in a work [34].

It has been recently shown that SCD patients have significantly higher glutathione peroxidase (GPx) and superoxide dismutase (SOD) activities than do healthy controls [35]. SODs, including $\mathrm{Cu}-$, $\mathrm{Zn}$ - and Mn-SODs and extracellular SODs, are protective enzymes against oxidative stress. They can specifically scavenge $\mathrm{O}_{2} \bullet$ by catalyzing its dismutation to hydrogen peroxide and molecular oxygen. Mn-SOD, which is a mitochondrial form of SOD, is involved in controlling dioxygen toxicity in the mitochondrion, an organelle of 
extreme oxidative load [36]. As found in [37], a structural mutation of thymine (T) to cytosine (C) substitution in the coding sequence of Mn-SOD gene, changes the amino acid codon at -9 position in the signal peptide from valine (GTT) to alanine (GCT). This signal peptide is removed during processing to a mature enzyme and plays a key role in targeting the enzyme to the mitochondria. Based on the plethora of published reviews and works on SOD in relations with SCD in different climes, this work was therefore undertaken to investigate same relationship in south-Eastern Nigeria to ascertain whether or not Mn-SOD polymorphism contributes to SCD pathophysiology in our environment.

\section{Materials and Methods}

\section{Study Design}

This study was a case control study carried out at the University of Nigeria Teaching Hospital (UNTH) Ituku-Ozalla, Nigeria from February 2020 to December 2020. The study recruited a total of 50 subjects which included 20 SCD patients (SS), 15 healthy sickle cell carriers (AS) and 15 healthy non-carriers (AA), with the last two groups serving as control groups.

\section{Ethical Approval}

The study was conducted in accordance with the Helsinki declaration, 2013 version. Ethical clearance certificate with approval number NHREC/05/01/2008B-FWA00002458$1 \mathrm{RB} 00002323$ and reference number UNTH/CSA/329/VOL.5 was issued by the UNTH Health Research Ethics Committee, dated 12/02/2020. Written informed consents were collected from patients willing to participate in the study. The privacy of patients were kept confidential and patients were free to withdraw from the study at any point in time.

\section{Inclusion/Exclusion Criteria}

SCD patients already diagnosed and being followed up at the UNTH Sickle Cell Clinic, who visited clinics on routine checkups were recruited for the study and their blood collected as test samples. Patients with severe malaria or critical health complications, and those who were admitted at the hospital were excluded from the study. Also, pregnant and breast-feeding women as well as HIV positive patients and children were excluded from the study. Blood samples for the controls were randomly collected from the UNTH Blood Bank where healthy donors' blood samples were stored, and sent to RiteCare Hospital (Enugu, Nigeria) where their haemoglobin types were determined using HemoTypeSC screening kit.

\section{Sample Collection}

A total volume of $3 \mathrm{ml}$ of blood was collected from each patient and transferred into anticoagulant tube (EDTA) and stored at $-80^{\circ} \mathrm{C}$ according to reported methods of storage [38].

\section{DNA Extraction}

Human genomic DNA was extracted from blood samples using the Zymo research DNA extraction kit according to the manufacturer's recommendations. This was done at the Biotech Lab of Godfrey Okoye University, Emene, Enugu, Nigeria. Proteinase K solution was prepared by adding $1040 \mu$ lo $20 \mathrm{mg}$ tube of proteinase $\mathrm{K}$, and stored at $-20{ }^{\circ} \mathrm{C}$. Two hundred (200) $\mu \mathrm{l}$ Biofluid and Cell Buffer, and $20 \mu \mathrm{l}$ proteinase $\mathrm{K}$ were added to $200 \mu \mathrm{l}$ of each of the blood samples in a microcentrifuge tube. The mixture was thoroughly vortexed for about 10 minutes and then incubated at $550 \mathrm{C}$ for 10 minutes in a waterbath. One volume (i.e. $420 \mu \mathrm{l}$ ) of Genomic Binding Buffer was added to the mixture, and mixed thoroughly. The whole mixture was transferred to a ZymoSpinTM IIC-XLR Column in a Collection Tube, centrifuged at about $12000 x g$ for 1 minute. The collection tube was then discarded with the flow content. Four hundred (400) $\mu \mathrm{l}$ of DNA Pre-Wash Buffer was added to the column in a new collection tube and centrifuged for another 1 minute. The collection tube was emptied of the flow content. Seven hundred (700) $\mu \mathrm{l}$ of g-DNA Wash Buffer was added and centrifuged for 1 minute. The collection tube was again emptied of its flow content. Two hundred (200) $\mu$ l of g-DNA Wash Buffer was added for the final washing, and centrifuged for another 1 minute. The collection tube was this time discarded with its flow content. The DNA was then eluted by adding 50 $\mu$ l of DNA Elution Buffer to the column in clean microcentrifuge tube, incubated at room temperature, and then centrifuged for 1 minute. The column was finally discarded, and the DNA-containing microcentrifuges for all the samples were stored at $-20^{\circ} \mathrm{C}$.

\section{Genotyping Alanine/Valine Polymorphism of Mn-SOD Gene}

An alanine/valine polymorphism in the signal peptide of Mn-SOD gene was evaluated using a primer pair (forward 5'ACCAGCAGGCAGCTGGCGCCGG3' and reverse 5'GCGTTGATGTGAGGTTCCAG3') as reported in [39] to amplify a $107 \mathrm{bp}$ fragment. Polymerase chain reaction (PCR) amplification of the genomic DNA was performed in a total volume of $25 \mu \mathrm{l}$, containing $5 \mu \mathrm{l}$ of $50 \mathrm{ng}$ genomic DNA, $1 \mu \mathrm{l}$ of $10 \mathrm{pmol} / \mu \mathrm{l}$ of each primer, $12.5 \mu$ l of master mix (Maxime PCR PreMix Kit (i-Taq), iNtRON biotechnology), and $5.5 \mu$ of water to make up the volume to $25 \mu$ l. PCR conditions involved an initial denaturation of DNA at $95^{\circ} \mathrm{C}$ for $5 \mathrm{~min}$, followed by 35 cycles of amplification at $95^{\circ} \mathrm{C}$ for 1 min (melting), $61^{\circ} \mathrm{C}$ for $1 \mathrm{~min}$ (annealing), and $72^{\circ} \mathrm{C}$ for $2 \mathrm{~min}$, and a final extension at $72^{\circ} \mathrm{C}$ for $7 \mathrm{~min}$. The resulting $107 \mathrm{bp}$ PCR product was digested with the restriction endonuclease NgoM IV at $37^{\circ} \mathrm{C}$ for $16 \mathrm{~h}$ according to manufacturer recommendations and digestion products were analyzed following electrophoresis on 3\% agarose gel stained with ethidium bromide $(0.5 \mu \mathrm{g} / \mathrm{ml})$. Restriction enzyme digestion results in a $107 \mathrm{bp}$ product (allele 1 Val-9) or $89 \mathrm{bp}$ and $18 \mathrm{bp}$ products (allele 2 Ala-9) or both giving three bands on the gel. 


\section{Statistical Analysis}

Data was analyzed using Hardy-Weinberg equilibrium equation, $p 2+2 p q+q 2$ where $p$ and $q$ are the two traits or polymorphisms being studied. The genotype frequencies, gotten using the above formula, were used to analyze the results.

\section{Results}

Human genomic DNA was extracted from 20 SS, 15 AA and 13 AS blood samples using the Zymo research DNA extraction kit following manufacturer recommendations. The result of the extraction was run on a $2 \%$ agarose gel for a qualitative verification of DNA presence. The gels for the DNA extracts are shown in (Plates $1 \& 2)$.

\section{PCR for Mn-SOD Gene Region}

An alanine/valine polymorphism in the signal peptide of Mn-SOD gene was evaluated using a primer pair (forward 5'ACCAGCAGGCAGCTGGCGCCGG3' and reverse 5'GCGTTGATGTGAGGTTCCAG3') as reported in [39] to amplify a $107 \mathrm{bp}$ fragment. The $107 \mathrm{bp}$ DNA segment for the SS, AS, AA samples as shown by $2 \%$ agarose gel are shown in (Plates $3 \& 4$ ).

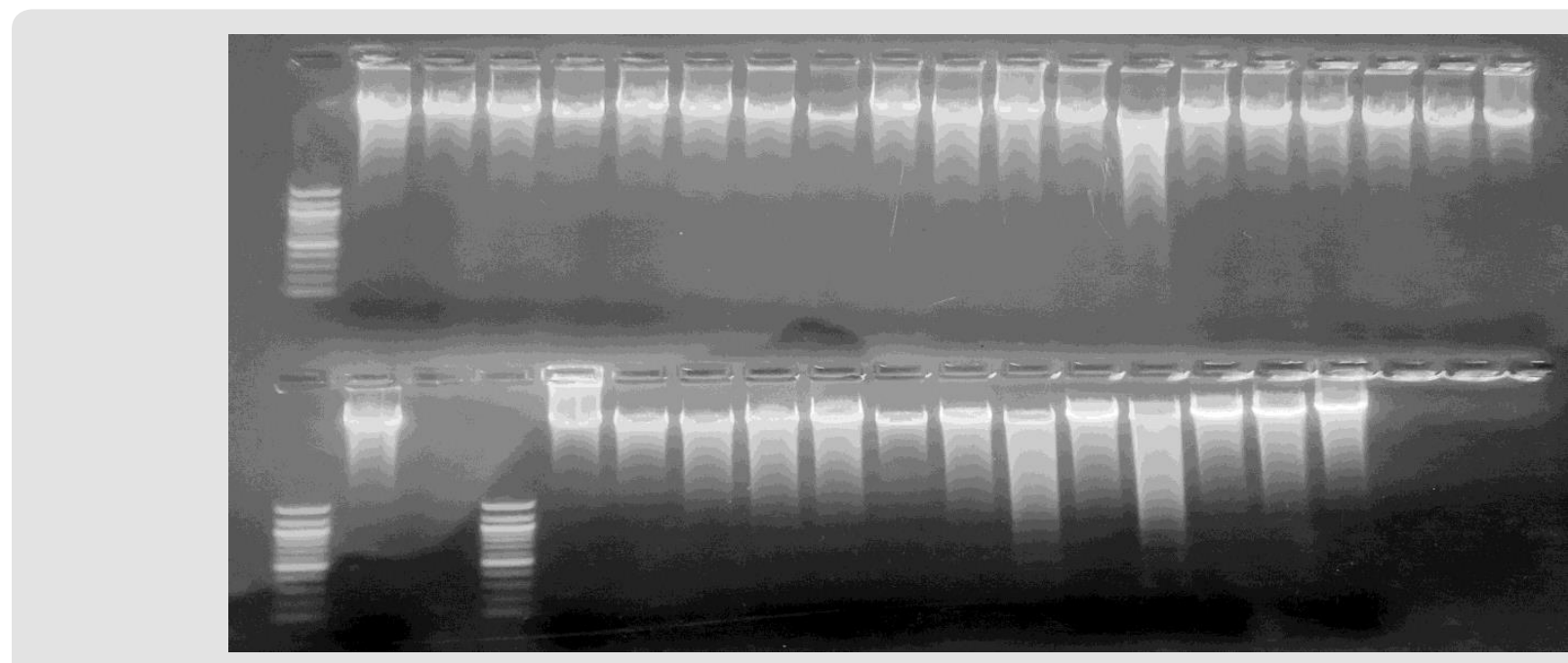

Plate 1: DNA bands on the gel 1-20 represent SS DNA; 36-48 represent AS DNA.

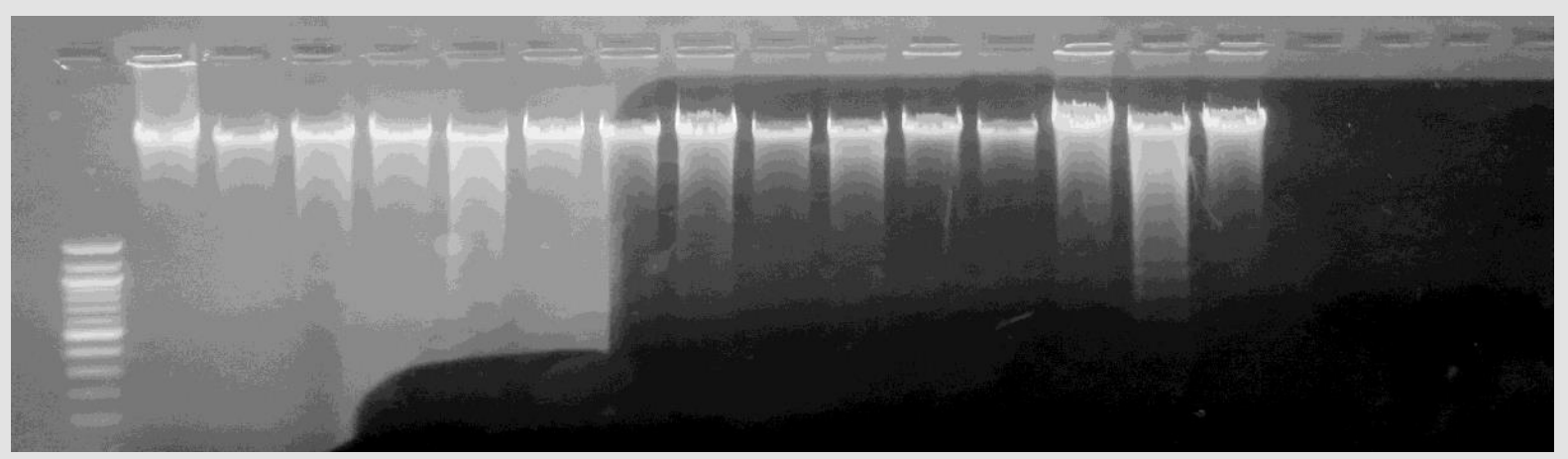

Plate 2: DNA bands on the gel 21-35 represent AA DNA. 


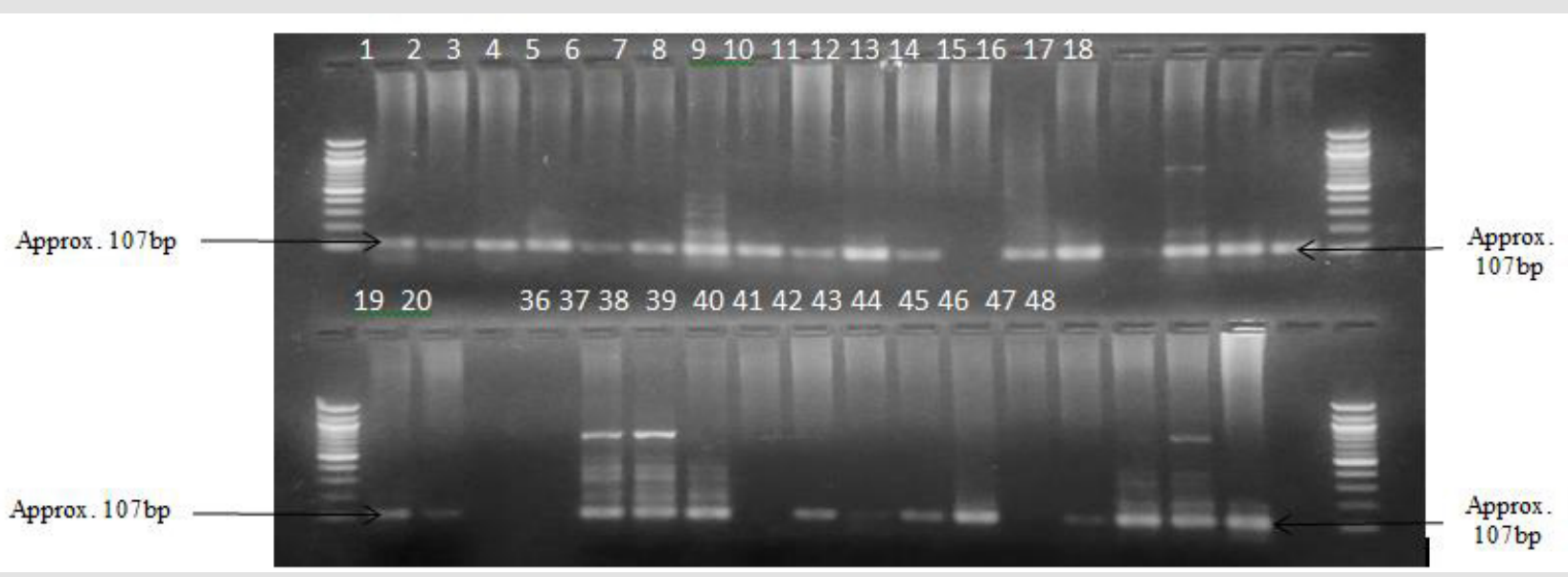

Plate 3: Presence of the amplified DNA region corresponding to 107bp band region on the gel 1-20 represent those of SS DNA; 36-48 represent those of AS DNA. (NB: Multiple bands in each lane as seen on the gel are possibly impurities).

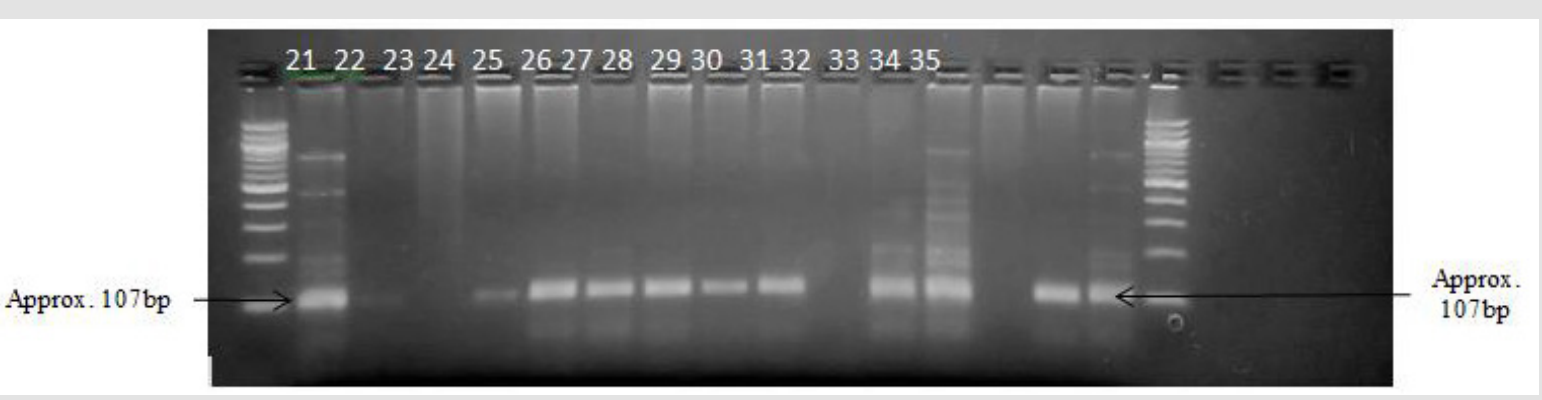

Plate 4: Presence of the amplified DNA region corresponding to 107bp band region on the gel 1-20 represent those of SS DNA; 36-48 represent those of AS DNA. (NB: Multiple bands in each lane as seen on the gel are possibly impurities).

\section{Restriction Enzyme Digestion of Mn-SOD Amplicons using NgoMIV}

The amplicons from the Mn-SOD primer PCR amplication were digested using NgoMIV restriction enzyme according to reports of [39]. After 16 hours digestion at $37^{\circ} \mathrm{C}$, the products were run on a $3 \%$ gel. The results are presented below in (Plates 5 \& 6]. (Table 1 ) shows a 0.67 genotype frequency of $\mathrm{VV}$ in the test group as can be seen from the gel bands in plate 5. The lanes having only one band around $107 \mathrm{bp}$ as measured from the $100 \mathrm{bp}$ molecular ladder, show uncut $107 \mathrm{bp}$ DNA fragment which implies the presence of valine at that $9^{\text {th }}$ position in the signal sequence. There is 0.15 frequency of the same genotype in the control group, as can be seen from the gel bands in plates $5 \& 6$. There is 0.27 frequency for AA genotype in the test group as seen from the bands in the plate 5 . The lanes having bands slightly below $100 \mathrm{bp}$ imply the presence of alanine due to the digestion which resulted to $89 \mathrm{bp}$ restriction fragments. There is 0.50 frequency of the same genotype in the control group. There is 0.06 frequency for VA in the test group and 0.35 in the control group. The heterozygous genotype is a result of the presence of both the undigested 107bp and the digested 89bp DNA fragments, thereby giving rise to bands at both the $107 \mathrm{bp}$ and $89 \mathrm{bp}$ regions on the electrophoretic gel. These can be seen on (Plates 5 \& 6).

Table 1.

\begin{tabular}{|c|c|c|c|c|}
\hline Sample Group & VV (107bp) & AA (89bp/18bp) & VA (107bp/89bp/18bp) & Void \\
\hline SS ( $\mathrm{n}=20)$ & $10(0.67)$ & $4(0.27)$ & $1(0.06)$ & 5 \\
\hline AA $(\mathrm{n}=15)$ & $0(0.0)$ & $8(0.73)$ & $3(0.27)$ & 4 \\
\hline AS $(\mathrm{n}=13)$ & $3(0.33)$ & $2(0.22)$ & $4(0.44)$ & 4 \\
\hline AS + AA (n = 28) & $3(0.15)$ & $10(0.50)$ & $7(0.35)$ & 8 \\
\hline
\end{tabular}

Note: (NB: AS + AA = the control group). 


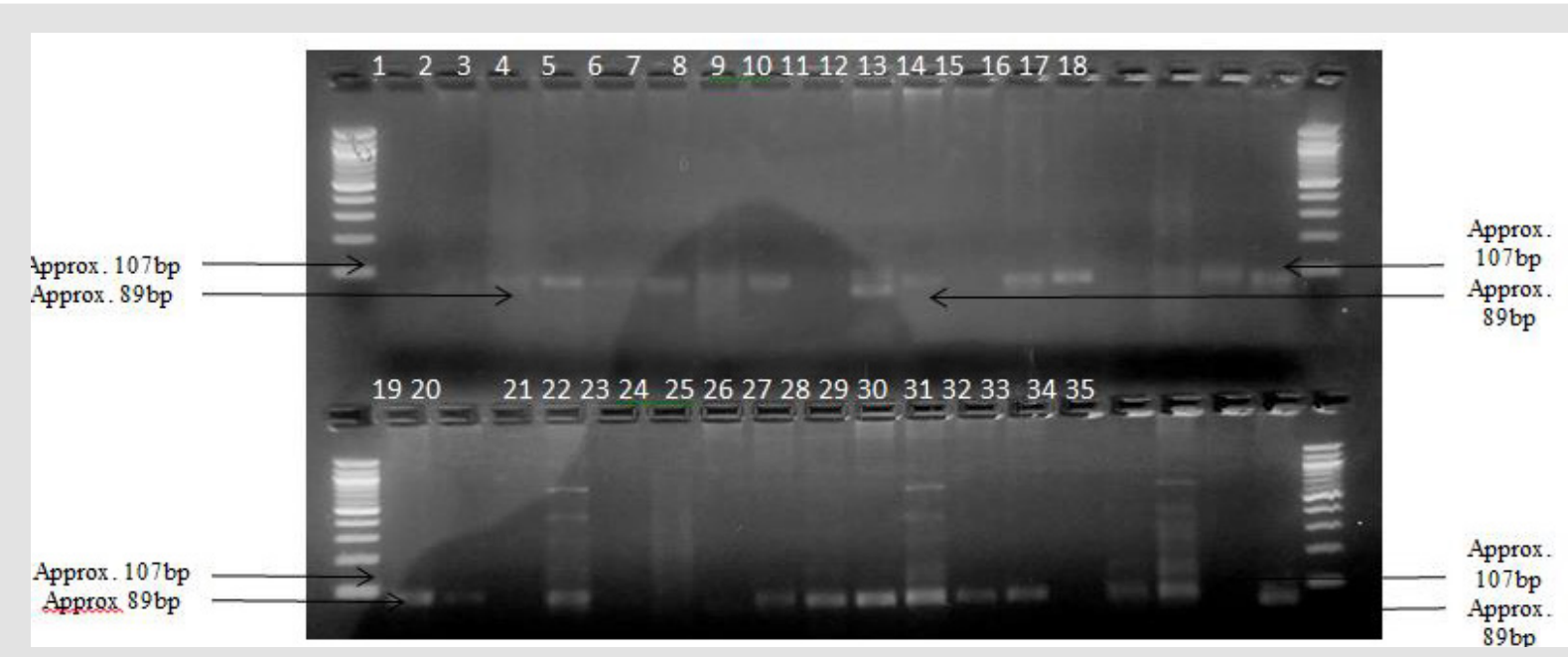

Plate 5: Amplified DNA digest fragment by NgoMIV based on the presence/absence of the restriction sites 1-20 represent those of SS DNA; 21-35 represent those of AA DNA. Lanes 3,4,5,6,7,8,11,13,14,17 are V/V; lanes 2,18,19,20,21,24,25,26,27,29,30,35 are A/A; lanes 10,28,32,33 are $\mathrm{V} / \mathrm{A}$.

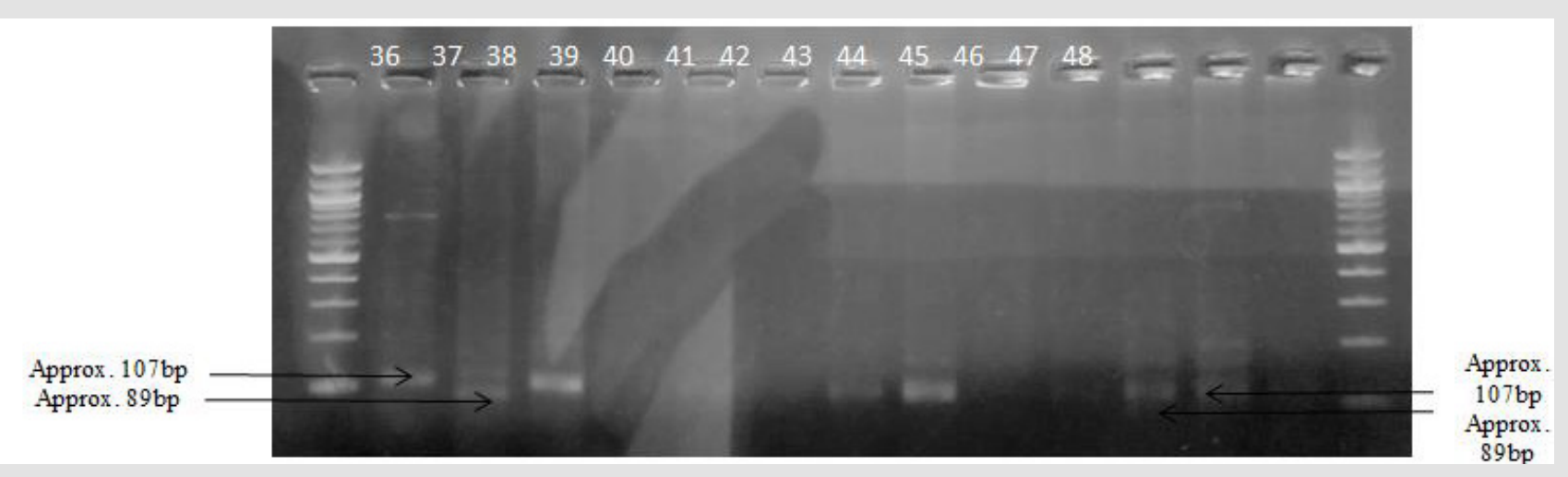

Plate 6: Amplified DNA digest fragment by NgoMIV based on the presence/absence of the restriction sites. 36-48 represent those of AS DNA. Lanes 36,38,40 are V/V; lanes 42,45, are A/A; lanes 37,43,46,47 are V/A.

\section{Discussion}

Ala-9-Val polymorphism in the signal peptide of human MnSOD genes has been fingered in various disease states ranging from sickle cell disease in other studies in other climes [39], diabetic neuropathy in diabetes mellitus I [40] and breast cancer [41], hence the justification for this study in our own clime. This work studied the association of Ala-9-Val polymorphism in the signal peptide of human Mn-SOD genes in the test group, sickle cell patients (SS), in comparison with the carriers (AS) and non-carriers (AA), with a view to ascertaining any involvement in oxidative stress and other clinical manifestations of the SCD crisis. SOD is a very important oxidative free radical scavenging enzyme. In this present study, the technique of restriction fragment length polymorphism (RFLP) was used to evaluate the single nucleotide polymorphism (SNP) in the various research groups. NgoMIV is a type II restriction enzyme with restriction site at $5^{\prime}$...G|CCGGC.... $3^{\prime}$ in both forward and reverse direction. If the 9th codon is GCC (Ala), then digestion with NgoM IV produces two DNA fragments, 89 and $18 \mathrm{bp}$ in length. If the codon is GTT (Val), the amplified product is not digested with NgoM IV and remains as a whole undigested 107bp DNA fragment. If the genotype is heterozygous, the two fragments plus the whole uncut DNA fragment are seen as three bands on the gel. The results in the test group show val/val genotype frequency to be 0.67 , ala/ala 0.27 and val/ala 0.06. In the control groups, the results seem to show an opposite trend, in which there is val/val frequency of 0.15 , ala/ ala 0.5 and val/ala of 0.35 . There is therefore, a predominance of $\mathrm{val} / \mathrm{val}$ genotype in the test group whereas there is more ala/ala in the control group, which could be said to be an association of the polymorphism with the SCD. This is contrary to the earlier work [39] which showed no association of the polymorphism with the disease. 


\section{Conclusion}

In conclusion, the findings of this research suggest that Ala-9-Val polymorphism in Mn-SOD gene is associated with SCD. This means that Ala-9-Val polymorphism in Mn-SOD gene could act as genetic modifiers of phenotypic outcome such as the level of oxidative stress of these patients in the region under study. However, there may be ethnic and geographical differences probably due to evolutionary diversity. More so, further investigation with large sample size is needed to confirm this association.

\section{Recommendation}

Larger sample size should be employed for further investigation of the association between these genes and SCD. They should also be investigated in connection with other oxidative free radical enzyme genes such as peroxidases, catalases, glutathione reductase, glutathione peroxidases and glutathione S-transferases. Inter- and intra-ethnic and geographical evolutionary factors should also be considered in further researches.

\section{Declaration of Interest}

The authors declare that they have no known competing financial interests or personal relationships that could have appeared to influence the work reported in this paper.

\section{Acknowledgment}

We are grateful for the support, cooperation, and trust of the patients who released their blood samples for this research. We are also grateful to the medical doctors in the Haematology Clinic and other personnel of UNTH Ituku-Ozalla for their support and cooperation. We also appreciate the assistance of the staff of RiteCare Hospital, Enugu, Nigeria. We also appreciate the cooperation of all the staff of Biotech Lab, Godfrey Okoye University, Emene, Enugu, Nigeria.

\section{Funding}

This research did not receive any specific grant from funding agencies in the public, commercial, or not-for-profit sectors.

\section{References}

1. Sundd P, Gladwin MP, Novelli EM (2019) Pathophysiology of Sickle Cell Disease. Annual Review of Pathology 14: 263-292.

2. Konotey-Ahulu FID (1973) Effect of Environment on Sickle Cell Disease in West Africa; Epidemiological and Clinical Considerations. In Abramson H, et al. (Eds.)., Sickle cell disease, diagnosis, management, education and research. St. Louis: The CV. Mosby Company USA 1973: 20-38.

3. Desai DV, Hiren D (2004) Sickle Cell Disease. History and Origin. The Internet Journal of Hematology 2: 47.

4. Stuart MJ, Nagel RL (2004) Sickle-cell disease. Lancet 364(9442): 13431360.

5. Lorenzi TF (2006) Manual de hematologia propedêutica e clínica (4 Edn.)., Rio de Janeiro: Guanabara Koogan.
6. Weatherall DJ, Clegg JB (2001) Inherited haemoglobin disorders: an increasing global health problem. Bulletin of the World Health Organization 79(8): 704-712.

7. Steinberg MH (2008) Sickle Cell Anemia, the First Molecular Disease: Overview of Molecular Etiology, Pathophysiology, and Therapeutic Approaches. The Scientific World Journal 8: 1295-1324.

8. Jones P (2008) Sickle Cell Disease (Gene \& Disease) (1 $1^{\text {st }}$ Edn.)., Chelsea House Publishers New York.

9. Chirico EN, Pialoux V (2012) Role of oxidative stress in the pathogenesis of sickle cell disease. International Union of Biochemistry and Molecular Biology-Life 64(1): 72-80.

10. Kaur M, Dangi CBS, Singh M (2013) An overview on sickle cell disease profile. Asian Journal of Pharmaceutical and Clinical Research 6(1): 2537.

11. Kohne E, Kleihauer E (2010) Hemoglobinopathies: A Longitudinal Study Over Four Decades. Deutsches Ärzteblatt International 107(5): 65-71.

12. Weatherall DJ, Clegg JB, Higgs DR, Wood WG (2000) The Hmoglobinopathies. In: Valle DL, Antonarakis S, Ballabio A, Beaudet AL and Mitchell GA (Eds.)., The Online Metabolic and Molecular Bases of Inherited Disease ( $8^{\mathrm{h}}$ Edn.)., McGraw-Hill, New York.

13. Petrides PE, Beykirch MK, Kohne E (2008) The high oxygen-affinity Hemoglobin Johnstown $\beta 109$ (G11) Val-Leu in a German kindred with an elevated erythrocyte hemoglobin content: Potential interaction with HFE mutation. Blood Cells, Molecules and Diseases 40(2): 180-182.

14. Wajcman H, Galactéros F (2005) Hemoglobins with high oxygen affinity leading to erythrocytosis, New variants and new concepts. Hemoglobin 29(2): 91-106.

15. Modell B, Darlison M (2008) Global Epidemiology of haemoglobin Disorders and Derived Service Indicators. Bulletin of the World Health Organization 86(6): 480-487.

16. (2011) WHO. Sickle-cell disease and other haemoglobin disorders. Media Centre. WHO Technical Report Series Fact sheet. World Health Organization, pp: 308.

17. (2013) WHO. Sickle cell disease prevention and control. Regional office for Africa, World Health Organization.

18. Serjeant GR, Serjeant BE (2001) The epidemiology of sickle cell disorder: a challenge for Africa. Archives of Ibadan Medicine 2(2): 46-52.

19. Okwi AL, Byarugaba W, Ndugwa CM, Parkes A, Ocaido M, et al. (2010) An up-date on the prevalence of sickle cell trait in Eastern and Western Uganda. BMC Blood Disorders 10: 5.

20. Uzoegwu PN, Onwurah AE (2003) Prevalence of haemoglobinopathy and malaria diseases in the population of old Aguata Division, Anambra State, Nigeria. Biokemistri 15(2): 57-66.

21. Halliwell B, Gutteridge JMC (2015) Free radicals in biology and medicine ( ${ }^{\text {th }}$ Edn.)., Oxford University Press; New York.

22. Winterboun CC (2008) Reconciling the chemistry and biology of reactive oxygen species. Nature Chemical Biology 4(5): 278-286.

23. Droge W (2002) Free radicals in the physiological control of cell function. Physiological Reviews 82(1): 47-95.

24. Tu BP, Weissman JS (2004) Oxidative protein folding in eukaryotes: mechanisms and consequences. Journal of Cell Biology 164(3): 341-346.

25. Aslan M, Ryan TM, Adler B, Townes TM, Parks DA, et al. (2001) Oxygen radical inhibition of nitric oxide-dependent vascular function in sickle cell disease. Proceedings of the National Academy of Science USA 98(26): 15215-15220.

26. Klings ES, Farber HW (2001) Role of free radicals in the pathogenesis of acute chest syndrome in sickle cell disease. Respiratory Research 2(5): 280-285. 
27. Nagababu E, Fabry ME, Nagel RL, Rifkind JM (2008) Heme Degradation and Oxidative Stress in Murine Models for Hemoglobinopathies: Thalassemia, Sickle Cell Disease and Hemoglobin C Disease. Blood Cells Molecules and Diseases 41(1): 61-66.

28. Akohoue SA, Shankar S, Milne GL, Morrow J, Chen KY, et al. (2007) Energy expenditure, inflammation, and oxidative stress in steady-state adolescents with sickle cell anemia. Pediatrics Research 61(2): 233-238.

29. Junior EB, Da Silva DG, Torres Lde S, De Almeida EA, Cancado RD, et al. (2012) Oxidative stress and antioxidant capacity in sickle cell anaemia patients receiving different treatments and medications for different periods of time. Annals of hematology 91(4): 479-489.

30. Walter PB, Fung EB, Killilea DW, Jiang Q, Hudes M, et al. (2006) Oxidative stress and inflammation in iron-overloaded patients with $\beta$-thalassaemia or sickle cell disease. British Journal of Haematology 135(2): 254-263.

31. Wood KC, Granger DN (2007) Sickle cell disease: Role of reactive oxygen and nitrogen metabolites. Clinical and Experimental Pharmacology and Physiology 34(9): 926-932.

32. Belcher JD, Beckman JD, Balla G, Balla J, Vercellotti G (2010) Heme degradation and vascular injury. Antioxidant Redox Signal 12(2): 233248.

33. Yoshihito I (2012) Anemia Caused by Oxidative Stress, p. 50-62.

34. Muskiet FA, Muskiet FD, Meiborg G (1991) Supplementation of patients with homozygous sickle cell disease with zinc, alpha-tocopherol, vitamin C, soybean oil, and fish oil. American Journal of Clinical Nutrition 54(4): 736-744.

\section{ISSN: 2574-1241}

DOI: $10.26717 /$ BJSTR.2021.39.006366

Okonkwo Cyril Onyedikachi. Biomed J Sci \& Tech Res

(C) This work is licensed under Creative

Submission Link: https://biomedres.us/submit-manuscript.php
35. Manfredini V, Lazzaretti LL, Griebeler IH, Santin AP, Brandao VD, et al. (2008) Blood antioxidant parameters in sickle cell anemia patients in steady state. Journal of the National Medical Association 100(8): 897902.

36. Sanders SP, Zweier JL, Harrison SJ, Trush MA, Rembish SJ, et al. (1995) Spontaneous oxygen radical production at sites of antigen challenge in allergic subjects. American Journal of Respiratory and Critical Care Medicine 151(6): 1725-1733.

37. Fridovich I (1995) Superoxide radical and superoxide dismutase. Annual Review of Biochemistry 64(1): 97-112.

38. Bulla A, De Witt B, Ammerlaan W, Betsou F, Lescuyer P (2016) Blood DNA yield but not integrity or methylation is impacted after long-term storage. Biopreservation and Biobanking 14(1): 29-38.

39. Sogut S, Yonden Z, Kaya H, Oktar S, Tutanc M, et al. (2011) Ala-9Val polymorphism of Mn-SOD gene in sickle cell anemia. Genetics and Molecular Research 10(2): 828-833.

40. Chistyakov DA, Savost'anov KV, Zotova EV, Nosikov VV (2001). Polymorphisms in Mn-SOD and EC-SOD genes and their relationship to diabetic neuropathy in type I diabetics mellitus. BMC Medical Genetics 2: 4 .

41. Mitrunen K, Sillanpaa P, Kataja V, Eskelinen M, Kosma V, et al. (2001) Association between manganese superoxide dismutase (MnSOD) gene polymorphism and breast cancer risks. Carcinogenesis 22(5): 827-829.

$\begin{array}{ll}\text { BIOMEDICAL } & \text { Assets of Publishing with us } \\ \text { RESEARCHES } & \text { - Global archiving of articles } \\ \text { - Immediate, unrestricted online access }\end{array}$

